\title{
Narcissism of Executive Officer: Profit Quality of Government Corporation
}

\author{
P. Febrina ${ }^{\mathrm{a}}$, T. Wahyudi ${ }^{\mathrm{b}}$, Azwardic \\ Sriwijaya University, Palembang, Indonesia \\ ${ }^{a}$ https://orcid.org/0000-0002-7683-1447; b https://orcid.org/0000-0003-4056-5105; \\ c https://orcid.org/0000-0003-0066-2445
}

\begin{abstract}
The study was motivated by the increasingly widespread phenomenon of narcissism of CEOs in various companies throughout the world, including Indonesia.he purpose of this study was to determine the impact of narcissism of the Chief Executive Officer on the profit quality of the company.The study was conducted on the purposive sampling of 20 state-owned companies listed on the Indonesia Stock Exchange in 2015 to 2018. The impact of narcissism of the CEO on the profit quality and the financial performance of the company was assessed.The author provided the mathematical justification of some provisions of the issue. The Modified Jones Model was used to evaluatethe company's financial management. The data were analyzed by means of Multiple Liner Regression.The study showed that the narcissism of the CEO negatively affects the financial results of the company and leads to lower profits. This is consistent with the Upper Enchelons Theory, which states that the organization is a reflection of the values of its leader.

Keywords: Narcissism; Chief Executive Officer; Profit Quality; Financial Statements
\end{abstract}

For citation: Febrina P., Wahyudi T., Azwardi. Narcissism executive officer: The quality prodit on government corporation. Finance: Theory and Practice. 2019;23(6):131-142. DOI: 10.26794/2587-5671-2019-23-6-131-142

ОРИГИНАЛЬНАЯ СТАТЬЯ

\section{Нарциссизм генерального директора: влияние на финансовые результаты государственной корпорации}

\author{
П. Фебрина ${ }^{\mathrm{a}}$, Т. Вахьюди ${ }^{\mathrm{b}}$ Азварди \\ Университет Шривиджая, Палембанг, Индонезия \\ ${ }^{a}$ https://orcid.org/0000-0002-7683-1447; ' https://orcid.org/0000-0003-4056-5105; \\ chttps://orcid.org/0000-0003-0066-2445
}

\begin{abstract}
АННОТАЦИЯ
Исследуется явление, которое получает все большее распространение по всему миру, включая Индонезию - нарциссизм руководителей в различных компаниях. Цель данного исследования - определить влияние нарциссизма генерального директора на финансовые результаты компании. Исследование проведено на примере двадцати специально отобранных государственных компаний, зарегистрированных на Индонезийской фондовой бирже в 2015 2018 гг. Дается оценка влияния нарциссизма генерального директора на качество прибыли, финансовые показатели компании. Автор предлагает математическое обоснование некоторых положений проблемы. Оценка управления финансовой деятельностью компании проведена с помощью модифицированной модели Джонса. Данные проанализированы посредством множественной линейной регрессии. Исследование показало, что нарциссизм генерального директора отрицательно влияет на финансовые результаты компании и ведет к снижению прибыли. Это соответствует теории высших эшелонов, утверждающей, что организация является отражением ценностей лидера. Ключевые слова: нарциссизм; директор компании; прибыль; финансовая отчетность
\end{abstract}

Для цитирования: Фебрина П., ВахьюдиТ., Азварди. Нарциссизм генерального директора: влияние на финансовые результаты государственной корпорации. Финансы: теория и практика. 2019;23(6):131-142. DOI: 10.26794/25875671-2019-23-6-131-142 


\section{INTRODUCTION}

One important component in a company's financial statements that attracts the attention of the external parties is profit. Management that reports financial statements with conditions that are not in accordance with its circumstances will produce poor quality, and it will affect all users of financial statements.

In the success of a company, CEO has an important role which is reflected from the results of the company's performance. According to Helfert (1996) decisions taken individually by management represent company performance. In the accrual basis process, management may have opportunities to manipulate earnings or profit in order to increase or decrease the accrual rate in the income statement. Profit value cannot be explained based on market value if investors use profit to shape the market value of the company. This research on narcissism may be important for shareholders because narcissism can be ,an important responsibility on jobs (like a CEO) where a realistic conception of one's talents and abilities is very important" (Judge et al. 2006: 772). Responsibility arises because narcissism can affect collaboration, trust, risk taking, motivation, decision making, and long-term performance (Campbell et al. 2004, Judge et al. 2006). Not only does his research make its contribution by providing preliminary evidence regarding the nature of the relationship between CEO narcissism and accounting income, but it also begins to explore the impact of personality traits such as narcissism on the potential for incorrect financial reporting (Hobson and Resutek 2008; Schrand and Zechman 2012). Thus, for shareholders and even regulators, the influence of narcissism on CEO decisions, behavior, and motivation can be an important consideration.

PT. Telekomunikasi was an example of a company that conducted profit management by creating a net profit growth of 2 percent to Rp 7.4 trillion in the first half of this year, from Rp 7.29 trillion in net profit for the same period in 2014. However, in fact, the actual performance was rated below the expectation. Consequently, it resulted on declining share prices. Ariyanto Kurniawan, a Research Analyst at Mandiri Sekuritas, said that Telkom's net profit was pressured by higher maintenance costs that had to be paid in the first half of this year. "In addition, Telkom's early retirement program costs are also higher. The most recent case is still in the State-owned companies, Garuda Indonesia. As published on April 1, 2019, Garuda Indonesia reported its financial performance of fiscal year 2018 to the Indonesia Stock Exchange. In its financial statements, the company with the GIAA stock code managed to reap a net profit of US $\$ 809$ thousand, unlike to its condition on the previous year which suffered deficit US\$216.58 million.

The company held an Annual General Meeting of Shareholders (AGMS) in Jakarta whose one of the agenda was to approve the financial statements for the 2018 fiscal year. Two Garuda Indonesia commissioners, Chairul Tanjung and Dony Oskaria as representatives of PT Trans Airways expressed their objections through 'letter of objection' to the AGMS. Chairul had asked that the objection be read out at the AGM, but upon the decision of the chair of the meeting the request was not granted. The results of the shareholders' meeting finally approved the Garuda Indonesia financial report in 2018. Trans Airways believed that the US\$239.94 million transaction with Mahata was too highly significant, thus affecting Garuda Indonesia's financial balance sheet. If the nominal of the cooperation was not included as revenue, then the company actually still lost US\$ 244.96 million. Two commissioners believed that the impact of revenue recognition was confusing and misleading because Garuda Indonesia's finances had changed from previously loss to profit. This performance was quite surprising because in the third quarter of 2018 the company also lost US \$114.08 million.

In this phenomenon, if investors used earnings like this in decision making, the earnings contained in the financial statements could not explain the true quality of profit. Profit quality and the quality of financial statements were generally important for those who used financial statements for contractual purposes and investment decision making (Schipper and Vincent, 2003). This research was motivated by the increasingly widespread narcissism phenomenon of a CEO that occured in various companies in the world, including in Indonesia. The Telkom, Akra and Garuda cases attracted researchers to study CEO narcissism as one of the aspects that influenced the conditions and / or activities within the company. Some researches showed that CEO narcissism could encourage unethical actions in the company. State-Owned Enterprises became the unit of research analysis because this sector was the favorite of many investors. It was therefore not surprising that the Indonesian State Owned Enterprises were considered to have a competitive advantage for relatively high growth.

To determine the relationship of CEO narcissism with profit quality and financial statements, state- 
owned companies listed on the Indonesia Stock Exchange in the period of 2015-2018 were used in this study with the CEO's narcissism mindset as the independent variable, profit quality as the dependent variable and company size, DER, Auditor Reputation and Board of Commissioners' Educational Background as the control variables. Stateowned companies were choosen as the object of the research because they had been the main actor in the national economy. Furthermore, this study used a photo of the CEO in an annual report to measure the level of narcissism of the CEO. This measurement adapted the method carried out by Olsen et al. (2014). Crowe's theory also stated that the number of CEO photos displayed in an annual company report could represent the level of arrogance or superiority that they possessed. The quality of the company's profit was measured by profit management, spesifically accrual profit management. Accrual profit management was measured using the Modified Jones Model.

\section{LITERATURE REVIEW \\ The Upper Echelon Theory and Freud's Psychoanalyst Theory}

Zein (2016) stated that the theory of Upper Echelon could be used to help explain that knowledge, beliefs and characteristics could influence leaders. On the other hand, Wan Yusof (2010) emphasized that the theory of upper echelon provided company performance as the reflection of top management. Therefore it was important to study the characteristics of a leader. Leaders play an important role in strategic decision making and resource allocation. Hambrick and Mason, through Upper Echelon Theory, stated that the strategies chosen by leaders were the reflection of their values and cognitive abilities. This theory also shows that age, experience, education, social background, economic conditions, and the characteristics of the group they are associated to, are filters when they digest, analyze, and try to understand the anatomy of a problem. This determines their ability to interpret complex situations and in what way the situation must be managed. Then, Age, according to Hambrick and Mason and several other academics, was one of the important characteristics of leaders. This theory considered the concept of top management as the main strategic decision maker in the organization. Thus, strategic decisions made by leaders had a direct impact on organizational outcomes because executives who hade responsibility for the organization as a whole, their characteristics, what they do, and how they do it, specifically affected organizational outcomes (Finkelstein and Hambrick 1996).

Psychoanalysis is a branch of science developed by Sigmund Freud and his followers, as a study of the functions and psychological behaviors of humans. Sigmund Freud (1856-1939) was a pioneer of psychodynamic theory. The theory put forward by Freud focuses on the subconscious problem, as one aspect of one's personality. Freud's emphasis on the unconscious came from his tracking of the personal experiences of his patients, which found that events that occurred in childhood greatly influenced the patient's life in the future. His impression of the importance of the early period of human life, whose information was then embedded in the subconscious, convinced him that information in the subconscious was very important, because from that arose various emotional disturbances. Freud's psychoanalytic theory (2006) considered that human behavior was determined by innate instincts that are largely unconscious. This unconscious process according to Freud was the process of being affected by the behavior of the mind, fear or desires that were not based on the person. There was a structural division in human personality by Freud. The most important thing about the psychoanalysis approach is that human action has a cause. However, the causes are often unconscious motives, not rational reasons given by someone for their behavior. In the psychoanalyst's view, human personality is an interaction between idea, ego, and superego.

\section{Previous research}

Frino, et al (2015) stated in their paper that investigated the relationship between CEO narcissism and income manipulation that there was growing evidence that narcissistic leaders overly identify themselves with the organizations they led and spent enormous resources to achieve their goals, including involvement in unethical behavior. They provided evidence that companies with more narcissistic CEOs were more likely to conduct manipulation to present better profit. Their results highlighted the importance of the CEO's personality to the company's accounting decisions.

Rispayanto (2019) said that CEOs with high levels of narcissism focused more on setting company targets unrealistically. Highlighted on the bonus distribution scheme given by shareholders to the company's CEO, company profits were important to consider as an indicator of the CEO's success in managing the company, and at the same time would influence the decision to award the CEO. Too 
high and unrealistic targets set by a narcissistic CEO would encourage the CEO to take unethical actions by carrying out profit management in order to achieve predetermined profit targets. The higher narcissism owned by a CEO led to the lower quality of profit.

Researches conducted by Risjenbilt and Commandeur (2013) found evidence that CEO narcissism could encourage him to commit fraud on the financial statements of the companies they led. Narcissism among executives was developing. The study, mostly from the financial and management literature, had examined the relationship of overly confident CEOs and decisions related to corporate investment policies, acquisitions, CEO selection, corporate governance, and innovation (Malmendier and Tate 2005; Brown and Sarma 2007; Goel and Thakor 2008; Malmendier and Tate 2008; Galasso and Simcoe 2011). For instance, a current study by Schrand and Zechman (2011) looked at whether certain personality tendencies of CEOs were associated with a higher probability of being involved in earnings management. They explored why companies overestimated revenue by looking at how bias toward optimism was related to the excessive nature of trust that was manifested by executives. They provided evidence of how financial reporting errors could begin with unintentional mistakes due to optimism bias that was common in executives who were overly confident, and then grew into greater intentional profit management. Their overall findings highlighted that certain personality tendencies could have a large impact on accounting-related behaviors and decisions.

Armenic and Craig (2010) mentioned that a company's financial accounting had a special character that could facilitate CEO narcissism. Profits published in financial statements became an ideal means for narcissistic CEOs to meet their need for continual recognition of their excellence (Chatterjee and Hambric, 2007). Periodically published financial reports (for example: quarterly, annual, etc.) provided a conducive environment for narcissistic CEOs who needed to be rewarded in each financial reporting period (Armenic and Craig, 2010). Accounting capacity to express the results of various complex and diverse company activities in a single performance measurement mad accounting, with its main product in the form of financial statements CEOs could use to show their superiority (Armenic and Craig, 2010).

Chatterjee \& Hambrick (2007) stated that narcissistic relationships possessed by the CEO contained in the annual financial statements in the form of photographs could be risky for a CEO. Someone who had a high level of narcissism would focus more on the final goal achieved than the process of achieving that goal (Furtner et al., 2011; Morf \& Rhodewalt, 2001).

\section{HYPOTHESIS DEVELOPMENT \\ The unfluence of Chief Executive Officer Narcissism on profit quality}

Based on the theoretical basis and previous studies, it can be hypothesized that the higher the narcissism possessed by a Chief Executive Officer will lead to lower profit quality. Research on Narcissism Chief Executive Officer can be based on Upper Echelon theory. Thus the following hypothesis can be made:

H1: CEO narcissism has a negative effect on profit quality.

The influence of Company Size on profit quality Company Size is a measure that can explain how big or small a company is, which consists of the market value of shares, log size and total assets related to company profits. The company is divided into three groups, namely large companies, medium companies and small companies. From this description, the following hypothesis is made:

H2: Firm size has a positive effect on profit quality.

The influence of DER on profit quality

The amount of debt illustrates the quality of the company and the company's progress in the future. Therefore, if the leverage level of a company is high, it will have a tendency to conduct large profit management so that it can produce low profit quality. From this description, the following hypothesis is made:

H3: Leverage has a negative effect on profit quality.

\section{The influence of Auditors' Reputation on profit quality}

Previous studies mentioned that quality auditors will add credibility to profit information submitted by the company. To be able to protect their reputation, auditors must utilize superior knowledge to detect profit management. This shows that companies that use the services of reputable public accounting firms will have better profit quality. Based on this description, the following hypothis can be made: 
H4: Auditor's reputation has a positive effect on profit quality.

\section{The influence of the board of commissioner's educational background on profit quality}

Based on previous research, if the board of commissioners have a management education background, it is considered that decisions made will be more ethical and accounting fraud could be avoided. Education is very influential on the use of financial information. The level of education affects the use of accounting information, the higher the level of education the executive has, the higher the level of rationalization used in decision making by utilizing the use of accounting information. With the description above, a hypothesis can be made as follows:

H5: The educational background of the board of commissioners has a positive effect on earnings quality.

\section{RESEARCH METHOD}

This study consisted of Narcissism as the independent variable, Company Size, DER, Auditor Reputation and Board of Commissioners Education Background as control variables and Profit Quality as dependent variable. The author would conduct partial and simultaneous testings. Prior conducting the test, the writer would measure the independent and dependent variables with the specified proxy. Secondary data in this study were the annual financial statements of state-owned companies listed on the Indonesia Stock Exchange (BEI) in 2015-2018.

This was the quantitative data with secondary data in the form of financial and non-financial data of BUMN companies listed on the Indonesia Stock Exchange in the 2015-2018 period as the source. the independent variable measured from the CEO's photo in the company's annual report, and profit quality and company size data were obtained from the Indonesian Capital Market Directory (ICMD), Fact Book and financial statements. The data collection method was documentation, which was a type of data collection that examines various kinds of documents that were useful for analysis material. Documents collected were secondary documents in the form of annual finances that had been published by the companies studied on the IDX website (http://www.idx.co.id).

The population in this study were 20 state-owned companies that had been listed on the Indonesia
Stock Exchange in 2015 until the observation period in 2018. The sample was taken using purpose sampling.

To be able to find out the significance influence of the independent variable on the dependent variable, a linear regression model was used. A classic assumption test must be performed on the testing of this regression analysis tool to obtain valid results.

Equation:

$\mathrm{Y}=\mathrm{a}+\mathrm{b} 1$ (Narcissism CEO) $+\mathrm{b} 2$ (Size) $+\mathrm{b} 3$ (DER) + + b4 (AUD) + b5 (EDUC) + e

Information:

Y is Profit Quality

$\alpha$ is a constant

$\mathrm{X} 1$ is Narcissism CEO

$\mathrm{X} 2$ is Company Size

$\mathrm{X} 3$ is DER

$\mathrm{X} 4$ is the Auditor's Reputation

$\mathrm{X} 5$ is the educational background of the board of commissioners

$\beta 1$ is the CEO Narcissism regression coefficient

$\beta 2$ is the Firm Size regression coefficient

$\beta 3$ is the Financial Leverage regression coefficient

$\beta 4$ is the Auditor Reputation Regression Coefficient

$\beta 5$ is the regression coefficient of the educational background of the board of commissioners

$\varepsilon$ is Standard error

CEO narcissism was measured by the size of the CEO's photo in the company's annual report, adopting the method used by Olsen (2014), where the measurement was done by giving one point for an annual report that did not display financial statements, 2 points for an annual report that displayed a photo of the CEO along with other executives, 3 points for an annual report with a photo of the CEO himself with a size of less than half a page, 4 points for an annual report with a CEO's own photo that was more than half a page size but did not meet one full page, and 5 points for the company's annual report that displayed the CEO's own photo with a full page size.

In this study, profit quality was measured using absolute numbers from Accrual Earnings Management (AEM). Thus, the higher the AEM conducted by the company, the lower the quality of the profits owned by the company. Accrual earnings management measurements were carried out using the Modified Jones Model. Dechow et al. (1995) said a more robust model because this model included revenue-based earnings management that was not detected in the original Jones model formulation. The Jones (1991) model proposed a model that sim- 
plified the notion that non-discretionary accruals were constant. The model tried to control the effect of changes in the company's economic environment on non-discretionary accruals. The value of discretionary accruals (DACC) to measure the level of earnings of the modified Jones model (Modified Jones Model) in (Dechow et al., 1995). Modified Jones Model could detect earnings management better than other models similar to the results of research (Dechow, et al., 1995).

Company size variable could affect the extent of financial statement disclosure in the company. The larger company would have greater information compared with smaller companies. Because large companies would face greater political risk than small companies. In addition, large companies got more attention. The policy of disclosure of social and environmental responsibility would help companies to avoid huge costs due to community demands. Roychowdhury (2006) explains that company size can explain variants in earnings manipulation significantly. Several other studies provide evidence that company size had an impact on disclosure of social responsibility (Prior et al., 2008; Yip, 2011; and Kim et al., 2012). The size of the company was formulated as follows: SIZE $=\log$ (book value of total assets).

Leverage was the company's ability to fund its operation that would show the amount of collateral available to pay creditors. Leverage would be measured by Debt to Equity Ratio (DER).

The size of the KAP (public accounting firm) in this study was the difference in the size of the public accounting firm, where the size of the KAP was divided into two; big KAP (big 4) and small KAP (non big 4). Shockley (1981), Saksakotama and Cahyonowati (2014) dummy variables were used to measure KAP variables. If the client company was audited by a large KAP (big 4), then it would be given a value of 1 . But if the client company was audited by a small KAP (non big 4), then it would be given a value of 0 .

The educational background of the independent board of commissioners could be seen from the business education pursued by members of the board of commissioners compared the number of commissioners who possessed a total business and economic education background with the existing members of the board of commissioners. The total educational background of the independent board of commissioners could be seen in the Annual report of the company profile section of the board of commissioners.

\section{RESULT AND DISCUSSION}

Descriptive analysis was conducted to recognize patterns, summarize information in the data, and present the information in the desired form. Descriptive analysis in this study was conducted to find the mean and standard deviation of the variables tested in the study.

The population used in this study were 20 stateowned companies listed on the Indonesia Stock Exchange from 2015-2018. The following is the descriptive analysis of each research data using a statistics program (Table 1).

From the results of SPSS output above, the minimum value, maximum value, average and standard deviation of each research data are presented. NCEO shows the level of CEO narcissism seen from the photos attached to the annual report. NCEO of JSMR: PT Jasa Marga (Persero) Tbk, BBNI: PT Bank BNI (Persero) Tbk, and KRAS: PT Krakatau Steel (Persero) $T b k$ had the highest value of 5,000, which were constantly from 2015 to 2018 became the highest number for narcissism of the CEO; a lowest value of 1,000 and PT. ANTM: PT Aneka Tambang (Persero) Tbk in 2016 was in the lowest place with a value of 1 ; the average value was 4.04000 and the standard deviation was 1.0872170 . This showed that the average CEO of a BUMN company does have a high narcissism during the observation period, from 2015 to 2018 .

The control variable used in this study was profit quality. The first one was SIZE. The highest value of SIZE was 34.6563 possessed by BBRI: PT Bank BRI (Persero) Tbk with total assets of $1,202,252,094,000,000$ in 2018; the lowest value was 27.9543 possessed by INAF: PT. Indofarma (Persero) Tbk with total assets of 1,381,633,321,120 in 2016; the average was 31.526204 and a standard deviation was 1.6498986 .

DER highest value was 9.5600 represented by BBTN: PT Bank BTN (Persero) Tbk in 2015; the lowest value was .1100 presented by SMBR: PT Semen Baturaja (Persero) Tbk in 2015; the average value was 1.810200 and the standard deviation was 2.1226201 . This indicated that of all the 20 State-owned companies, the amount of debt used to finance business activities when compared to equity was 1.810200 .

The auditor reputation variable has the highest value of 1 ; the lowest value of 0 ; and the average value of .640000. It indicated that only 32 companies used auditors that were categorized as the Big Four, the remaining 18 companies used auditors that were not included in the Big Four category. The standard deviation was .4848732. 


\section{Descriptive Statistics}

\begin{tabular}{|l|c|c|c|c|c|}
\hline & N & Minimum & Maximum & Mean & Std. Deviation \\
\hline Y & 50 & -9.9649 & -.3437 & -1.845340 & 1.7938781 \\
\hline NCEO & 50 & 1.0000 & 5.0000 & 4.040000 & 1.0872170 \\
\hline SIZE & 50 & 27.9543 & 34.6563 & 31.526204 & 1.6498986 \\
\hline DER & 50 & .1100 & 9.5600 & 1.810200 & 2.1226201 \\
\hline AUD & 50 & .0000 & 1.0000 & .640000 & .4848732 \\
\hline EDUC & 50 & .0000 & 87.5000 & 30.006600 & 21.7501255 \\
\hline $\begin{array}{l}\text { Valid N } \\
\text { (Listwise) }\end{array}$ & 50 & & & & \\
\hline
\end{tabular}

Source: compiled by the author.

Normality Test Result

Table 2

\section{One-Sample Kolmogorov-Smirnov Test}

\begin{tabular}{|c|c|}
\hline & Unstandardiz ed Residual \\
\hline Normal Parameters a.b Mean & 50 \\
Std.Deviation & $0 \mathrm{E}-7$ \\
Most Extreme Differences Absolute & 1.56159106 \\
Positive & .141 \\
Negative & .122 \\
Kolmogorov-Smirnov Z & -.141 \\
Asymp. Sig. (2-tailed) & .999 \\
\hline
\end{tabular}

Source: compiled by the author.

\section{Multicollinearity Test Result}

\begin{tabular}{|c|c|c|c|c|c|c|c|c|}
\hline \multicolumn{9}{|c|}{ Coefficients $^{a}$} \\
\hline & \multirow{2}{*}{ Model } & \multicolumn{2}{|c|}{ Unstandardized Coefficients } & \multirow{2}{*}{$\begin{array}{c}\begin{array}{c}\text { Standardized } \\
\text { Coefficients }\end{array} \\
\text { Beta }\end{array}$} & \multirow{2}{*}{$\mathbf{T}$} & \multirow{2}{*}{ Sig. } & \multicolumn{2}{|c|}{ Collinearity Statistics } \\
\hline & & B & Std. Error & & & & Tolerance & VIF \\
\hline \multirow{6}{*}{1} & (Constant) & -11.911 & 6.929 & & -1.719 & .093 & & \\
\hline & $\mathrm{X} 1$ & .109 & .247 & .066 & .442 & .016 & .769 & 1.300 \\
\hline & $\times 2$ & .300 & .247 & .276 & 1.211 & .232 & .332 & 3.008 \\
\hline & X3 & -.379 & .144 & -.448 & -2.638 & .011 & .597 & 1.675 \\
\hline & $\mathrm{X} 4$ & .648 & .597 & .175 & 1.086 & .283 & .662 & 1.511 \\
\hline & $\times 5$ & .015 & .012 & .181 & 1.197 & .238 & .756 & 1.322 \\
\hline
\end{tabular}

Source: compiled by the author. 
Autocorrelation Test Result

Model Summay ${ }^{b}$

\begin{tabular}{|c|c|c|c|c|c|}
\hline Model & $\mathbf{R}$ & R Square & Adjustd R Square & $\begin{array}{c}\text { Std.Error of the } \\
\text { Estimate }\end{array}$ & $\begin{array}{c}\text { Durbin- } \\
\text { Watson }\end{array}$ \\
\hline 1 & $.492^{\mathrm{a}}$ & .242 & .156 & 1.6479310 & 1.914 \\
\hline
\end{tabular}

Source: compiled by the author.

Table 5

\section{Multiple Linear Regression Analysis Result Coefficients $^{a}$}

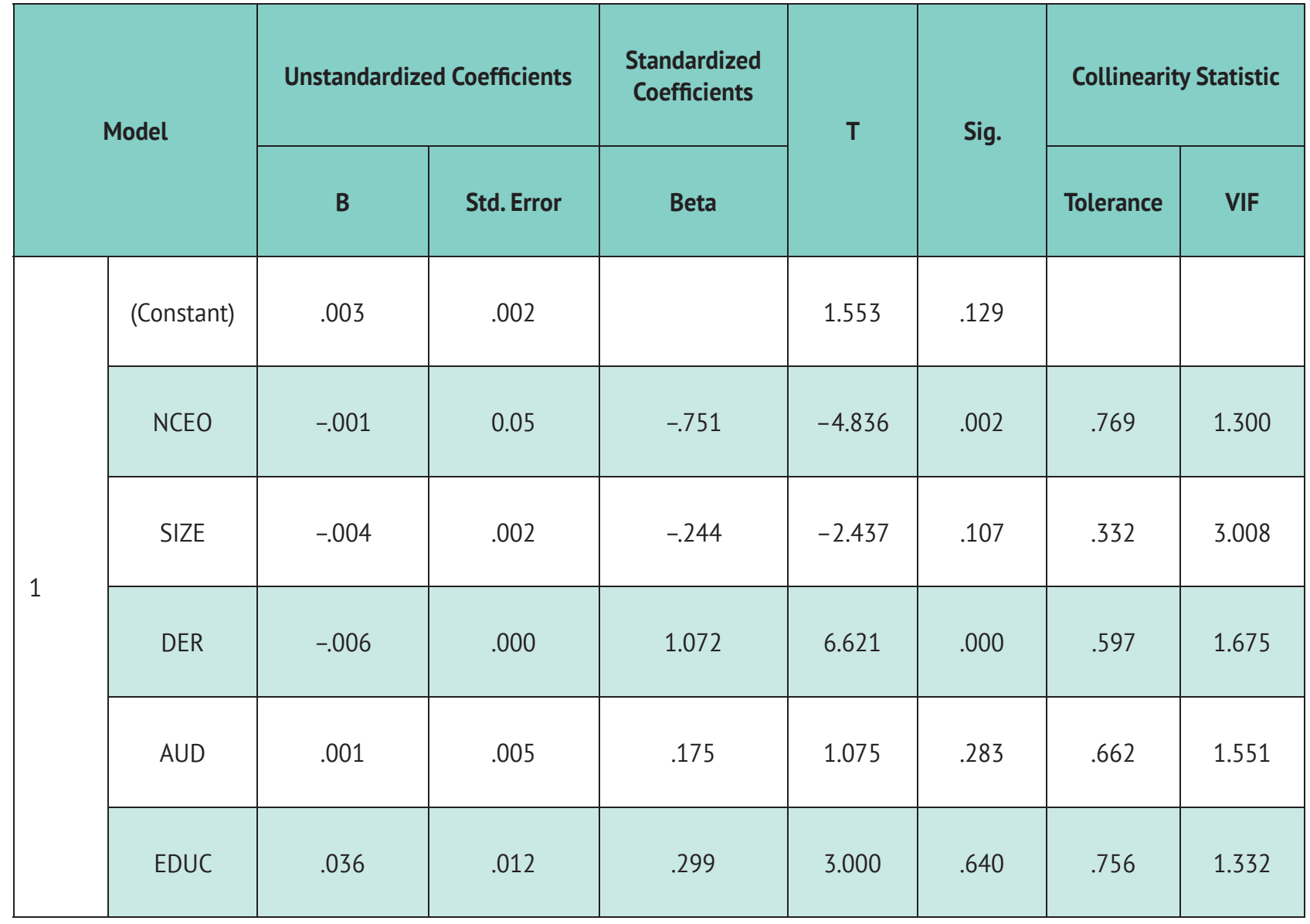

Source: compiled by the author.

The EDUC variable had the highest of 87.5000 represented by BMRI: PT Bank Mandiri (Persero) Tbk in 2016. This indicated that most CEOs and board of commissioners at BMRI have a management education background. The lowest value was .0000 represented ADHI: PT Adhi Karya (Persero) Tbk in 2018. EDUC had an average value of 30.006600 and a standard deviation of 21.7501255 . From the data distribution, it could be seen that there were still many boards of commissioners in BUMNs that did not have management background (Table 2).
After clearing data from outliers (data deviating far from the average), the Asymp.Sig. (2-tailed) value was 0.271 . The results indicated that the residual data in this regression model was normally distributed because of the Asymp value. Sig. (2-tailed) above 0.05 (Table 3).

Based on the multicollinearity test analysis results above, the tolerance value was $>0.1$ and VIF value was $<10$. These results showed that there was no multicollinearity problem in this regression model and could be used for further analysis (Table 4). 


\section{The Analysis of Determination Coeficient Test Result Model Summary ${ }^{b}$}

\begin{tabular}{|c|c|c|c|c|}
\hline Model & R & R. Square & Adjusted R Square & Std. Error of the Estimate \\
\hline 1 & $.607^{\mathrm{a}}$ & .368 & .344 & .0186640 \\
\hline
\end{tabular}

Source: compiled by the author.

\section{F Test Result}

\begin{tabular}{|l|c|c|c|c|c|}
\hline \multicolumn{1}{|c|}{ Model } & Sum of Squares & Df & Mean Square & F & Sig. \\
\hline 1 Regression & .015 & 3 & .005 & & \\
Residual & .026 & 76 & .000 & 14.781 & $.000^{\mathrm{b}}$ \\
Total & .042 & 79 & & \\
\hline
\end{tabular}

Source: compiled by the author.

\section{t Test Result \\ Coefficients $^{\mathrm{a}}$}

Table 8

\begin{tabular}{|c|c|c|c|c|c|c|}
\hline & \multirow{2}{*}{ Model } & \multicolumn{2}{|c|}{ Unstandardized Coefficients } & \multirow{2}{*}{$\begin{array}{c}\begin{array}{c}\text { Standardized } \\
\text { Coefficients }\end{array} \\
\text { Beta }\end{array}$} & \multirow{2}{*}{$\mathbf{t}$} & \multirow{2}{*}{ Sig. } \\
\hline & & B & Std. Error & & & \\
\hline \multirow{6}{*}{1} & (Constant) & .003 & .002 & & 1.553 & .129 \\
\hline & $\mathrm{X} 1$ &,- 001 & 0.05 & -.751 & -4.836 & .002 \\
\hline & $\times 2$ & -.004 & .002 & -.244 & -2.437 & .107 \\
\hline & X3 & -.006 & .000 & 1.072 & 6.621 & .000 \\
\hline & $X 4$ & .001 & .005 & .175 & 1.075 & .283 \\
\hline & $\times 5$ & .036 & .012 & .299 & 3.000 & .640 \\
\hline
\end{tabular}

Source: compiled by the author.

From the results in table 4 above, the Watson durbin was at 1,914 . This value then would be compared with the DW table with a sample size of 50 , four independent variables and a confidence level of $5 \%$ at the lower limit $(\mathrm{dl})=1,3779$ and upper limit $(\mathrm{du})=1.7214$. Because the DW value of 1.914 was between the upper limit $(\mathrm{du})=$ $=1.7214$ and $(4-\mathrm{du})=2.2786$, it could be concluded that autocorrelation did not occur (Table 5).

From the results of the multiple linear regression analysis above, the regression equation model developed in this study was as below:
$\mathrm{Y}=0.003+-0.001 \mathrm{NCEO}-0.004 \mathrm{SIZE}-0.06 \mathrm{DER}+$ +0.001 AUD + 0.36EDUC + e.

Based on the above analysis, the Narcissism variable of CEO, SIZE, DER had negative influences on profit quality while the Auditor Reputation and EDUC variables provided positive influences on profit quality (Table 6).

In the determination coefficient, the regression model obtained adjusted $R$ square value of 0.344 . This showed that $34.4 \%$ of profit management variations can be explained by the company size, financial lever- 
age, auditor's reputation, and board of commissioners' educational background as control variables, while the remaining $65.6 \%$ could be explained by other variables not included in this study.

According to Table 7, the $\mathrm{F}$ value calculated $_{\text {was }} 14.781$ with a significance value of $0.000<$ alpha 0.05 . It explained that all control variables such as company size, financial leverage, auditor reputation, and educational background of the board of commissioners jointly affected the profit quality (Table 8).

The first hypothesis looked at the influence of CEO Narcissism on profit quality. The test result using linear regression were presented in table 4.10. Based on the above test result, a regression coefficient was at -001 with a significance value of 0.02 $(<0.05)$. Thus, it could be concluded that Narcissism CEO had a negative effect on profit quality. Then, the first hypothesis which stated that CEO Narcissism negatively affected profit quality was accepted. The first hypothesis test result showed that Narcissism CEO negatively affected profit quality. These finding was in line with the results of researches conducted by Leela et al (2017), Vita and Slamet (2018) and Krishnan (2008). In other words, Narcissism CEO led to lower profit management. The higher the Narcissism of a CEO in a company was, the smaller the profit management actions taken by the company would be. This finding was in contrary to the results of researches done by Rispantyo (2019), Frino et al (2015), Lynn (2011), Campbell (2004), Chatterjee (2011), Daniel (2010), and Creig (2011) which stated that CEO Narcissism provided a positive effect on profit quality. Chatterjee and Hambrick (2006) stated that narcissism was one of the causes for someone to assume the power and influence they had (Kernberg, 1975). In addition, narcissism could help and arouse one's emotions for the advancement of his profession when it was linked to self-esteem. (Raskin, et al, 1991). Therefore, with narcissism, someone would try to create a positive image, which would also lead to optimism and a strong belief in the results obtained later. The result of this study was in line with the Upper Enchelon Theory (Ingersol et al, 2017) which suggested that the organization was a reflection of the values held by its leaders (Hambrick and Mason, 1984). The personality of the company leader would determine the various strategies, policies and practices that run in the company. State-owned companies were always under the supervision of the government so that the alleged practice of profit management or the desire to conduct profit manipulation was very small. The result of this study supported the statement.
The second hypothesis looked at the effect of company size on profit quality. Based on the test result, the regression coefficient was -0.004 with a significance value of $0.107(>0.05)$. Thus it could be concluded that company size had no effect on profit quality. Therefore, the second hypothesis which stated that company size had a positive effect on profit quality was rejected. The result of this study were supported by research by Palupi (2006), Collins and Kothari (1989) which mentioned that company size gave no effect on profit quality. This finding was also in line with Rizki's (2012). Watt and Zimmerman (1986) in their third hypothesis (the existence of an agency relationship between management and government) included in positive accounting theory stated that large companies which in many cases easily became the public spotlight had a strong urge not to be too accentuating profits because of concerns over the emergence of accusations of getting special facilities and monopolies from the government.

The third hypothesis looked for the effect of leverage on profit quality. Based on the test result, the regression coefficient was -0.006 with a significance value of $0.000(<0.05)$. Thus it could be concluded that leverage affected profit quality in a negative direction. Therefore the third hypothesis which stated that leverage had a negative effect on earnings quality was accepted. These results supported the research of Sadiah (2015), Ghosh and Moon (2010). Scott (2009) stated that investors would assume a negative effect on the use of debt in the company and that the company would prioritize debt payments rather than paying dividends. Therefore, the higher the leverage level of the company, the lower the profit quality because there was an indication that the management practiced poor profit management.

The fourth hypotheses aimed to see the effect of the auditor's reputation on profit quality. Based on the test result, the regression coefficient was 0.001 with a significance value of $0.283(<0.05)$. Thus it could be concluded that the Auditor's reputation did not affect profit quality. Therefore, the fourth hypothesis which stated that the company's Auditor Reputation had a positive effect on profit quality was rejected. This indicated that if a company was audited by a high-reputed auditor, the level of trust in the quality of its profits would get higher, thereby minimizing unlawful profit management practices.

The fifth hypothesis looked at the influence of the board of commissioner's educational background on profit quality. Based on the test result, the regression coefficient was 0.036 with a significance value of 0.640 $(<0.05)$. Thus it could be concluded that the educa- 
tional background of the board of commissioners had no effect on the quality of profit. Therefore, the fifth hypothesis which stated that the board of commissioners' educational background had a positive effect on profit quality was rejected. This result was in line with the research of Bagus (2014) and Setyaningrum (2012) mentioning that educational background had a significant effect on professional skills. The result of this research was in contrary to Kusumastuti et al (2006), Bray, Howard and Golan 1995) and Moerdiyanto (2011) which supported the positive impact of manager education on the company's stock performance.

\section{CONCLUSION}

Based on the results of the research on the influence of CEO narcissism on profit quality in the financial statements of state-owned enterprises in the 2015-2018 period, the following conclusions can be drawn. There was a relationship between CEO narcissism on company profit quality that provided a negative impact. This finding was con- sistent with the results of Frino et al (2015) stating that the higher the level of CEO narcissism, the higher the risk of profit management and led to lower profit quality. Likewise, the effect of DER on profit quality had a negative effect because the use of debt would be responded negatively by investors. Consequently, the company was assumed to prioritize debt payments rather than dividend payments. Therefore, the higher the leverage of the company, the lower the profit quality because there were indications that the management conducted unlawful and poor profit management practices. Since there was still lack of researches conducted on the narcissistic characteristics of a CEO, some limitations occured in this study. Future researchers could further expand the scope of the researches as this research used only stateowned enterprises as the research object. In addition, further researches were encouraged to redevelop this study by combining variables related to narcissism and other profit quality.

\section{REFERENCES}

1. Amernic J.H., Craig R. J. Accounting as a facilitator of extreme narcissism. Journal of Business Ethics. 2010;96(1):79-93. DOI: 10.1007/s10551-010-0450-0

2. Campbell W.K., Goodie A.S., Foster J.D. Narcissism, confidence, and risk attitude. Journal of Behavioral Decision Making. 2004;17(4):297-311. DOI: 10.1002/bdm.475

3. Campbell W.K., Hoffman B. J., Campbell S. M., Marchisio G. Narcissism in organizational contexts. Human Resource Management Review. 2011;21(4):268-284. DOI: 10.1016/j.hrmr.2010.10.007

4. Chatterjee A., Hambrick D.C. It's all about me: Narcissistic chief executive officers and their effects on company strategy and performance. Administrative Science Quarterly. 2007;52(3):351-386. DOI: 10.2189/ asqu.52.3.351

5. Dechow P. M., Sloan R. G., Sweeney A.P. Detecting earnings management. The Accounting Review. 1995;70(2):193-225.

6. Finkelstein S., Hambrick D.C. Strategic leadership: Top executives and their effects on organizations. St. Paul, MN: West Publishing Co.; 1996. 457 p.

7. Freud S. A general introduction to psychoanalysis. Transl. from Eng. Yogyakarta: Pustaka Pelajar; 2006. 707 p. (In Indones.).

8. Galasso A. Simcoe T. S. CEO overconfidence and innovation. Management Science. 2011;57(8):1469-1484. DOI: $10.1287 / \mathrm{mnsc} .1110 .1374$

9. Goel A.M., Thakor A.V. Overconfidence, CEO selection, and corporate governance. The Journal of Finance. 2008;63(6):2737-2784. DOI: 10.1111/j.1540-6261.2008.01412.x

10. Helfert E.A. Techniques of financial analysis. Transl. from Eng. Jakarta: Erlangga; 1996. 436 p. (In Indones.).

11. Ingersoll A.R., Glass C., Cook A., Olsen K.J. Power, status and expectations: How narcissism manifests among women CEOs. Journal of Business Ethics. 2019;158(4):893-907. DOI: 10.1007/s10551-017-3730-0

12. Judge T.A., LePine J.A., Rich B.L. Loving yourself abundantly: Relationship of the narcissistic personality to self- and other perceptions of workplace deviance, leadership, and task and contextual performance. Journal of Applied Psychology. 2006;91(4):762-776. DOI: 10.1037/0021-9010.91.4.762

13. Olsen K. J., Dworkis K. K., Young S. M. CEO narcissism and accounting: A picture of profits. Journal of Management Accounting Research. 2014;26(2):243-267. DOI: 10.2308/jmar-50638

14. Prior D., Surroca J., Tribó J.A. Are socially responsible managers really ethical? Exploring the relationship between earnings management and corporate social responsibility. Corporate Governance: An International Review. 2008;16(3):160-177. DOI: 10.1111/j.1467-8683.2008.00678.x 
15. Rijsenbilt A., Commandeur H. Narcissus enters the courtroom: CEO narcissism and fraud. Journal of Business Ethics. 2013;117(2):413-429. DOI: 10.1007/s10551-012-1528-7

16. Rispayanto. CEO narcissism and profit quality. Research Fair Unsiri. 2019:3(1). (In Indones.).

17. Roychowdhury S. Earnings management through real activities manipulation. Journal of Accounting and Economics. 2006;42(3):335-370. DOI: 10.1016/j.jacceco.2006.01.002

18. Schipper K., Vincent L. Earnings quality. Accounting Horizons. 2003;17(1S):97-110. DOI: 10.2308/ acch.2003.17.s-1.97

19. Yusoff W.F.W. Characteristics of boards of directors and board effectiveness: A study of Malaysian public listed companies. PhD thesis. Melbourne: Victoria University; 2010. 445 p. URL: http://vuir.vu.edu. au/15798/1/yusoff.pdf.

20. Zein A.K., Surya R.A.S., Silfi A. The effect of earnings growth, capital structure, liquidity and independent commissioners on earnings quality with independent commissioners moderated by the competence of independent commissioners: Study on manufacturing companies listed on the Indonesia Stock Exchange in the period 2013-2014. JOM Fekon. 2016;3(1):980-992. URL: https://jom.unri.ac.id/index.php/JOMFEKON/ article/view/10628/10284 (In Indones.).

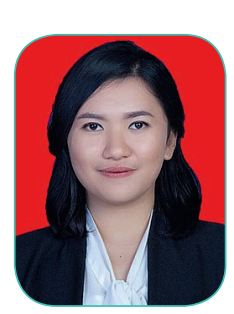

ABOUT THE AUTHORS / ИНФОРМАЦИЯ ОБ АВТОРАХ

Poppy Febrina - Bachelor of Economics, Master Student, Sriwijiaya University, Palembang, Indonesia

Поппи Фебрина - бакалавр в области экономики, студент магистратуры, Университет Шривиджая, Палембанг, Индонезия

poppyazora@yahoo.co.id

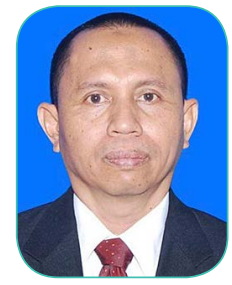

Tertiarto Wahyudi - Master Of Accountancy and financial information systems, lecturer, Sriwijaya University, Palembang, Indonesia

Tepmьярто Вахьюди - магистр наук в области бухгалтерского учета и финансовых информационных систем, преподаватель, Университет Шривиджая, Палембанг, Индонезия

tertiarto_wahyudi@unsri.ac.id

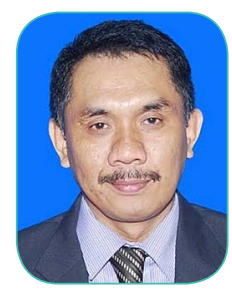

Azwardi - Master of Science of Economics, lecturer, Sriwijaya University, Palembang, Indonesia,

Азварди - магистр наук в области экономики, преподаватель, Университет Шривиджая, Палембанг, Индонезия

Azwardi_unsri@yahoo.com

\section{Authors' declared contribution:}

Poppy Febrina - Theoretical part, methodology, research data collection, analysis of data processing results. Tertiarto Wahyudi - Disscusion about adding control variables and research results.

Azwardi - Disscusion about research results and general conclusion.

\section{Заявленный вклад авторов:}

Поппи Фебрина - теоретическая часть, методология, сбор данных исследования, анализ результатов обработки данных.

Тертьярто Вахьюди - введение дополнительных контрольных переменных и результатов исследований. Азварди - анализ результатов исследования, общие выводы.

The article was submitted on 10.10.2019; revised on 24.10.2019 and accepted for publication on 20.11.2019. The authors read and approved the final version of the manuscript.

Статья поступила в редакцию: 10.10.2019; после рецензирования: 24.10.2019; принята к публикации 20.11.2019. Авторы прочитали и одобрили окончательный вариант рукописи. 